8 Andrews G, Slade T, Peters L. Classification in psychiatry: ICD-10 versus DSM-IV. Br J Psychiatry 1999; 174: 3-5

9 First MB, Pincus HA. Classification in psychiatry: ICD-10 v. DSM-IV.

A response. Br J Psychiatry 1999; 175: 205-9.

10 Cooper JE. Prospects for Chapter V of ICD-11 and DSM-V. Br J Psychiatry 2003; 183: 379-81.

11 World Health Organization. The ICD-10 Classification of Mental and Behavioural Disorders: Diagnostic Criteria for Research. World Health Organization, 1993.
12 WHO Collaborating Centre for Mental Health Research and Training. WHO Guide to Mental Health in Primary Care. Royal Society of Medicine Press, 2000.

13 Kendell R, Jablensky A. Distinguishing between the validity and utility of psychiatric diagnoses. Am J Psychiatry 2003; 160: 4-12.

14 Jablensky A, Kendell RE. Criteria for assessing a classification in psychiatry. In Psychiatric Diagnosis and Classification (eds M Maj, W Gaebel, JJ López-Ibor \& N Sartorius): 1-24. John Wiley, 2002.

\section{psychiatry in pictures}

\title{
Portrait of fellow patient (date unknown) by Denis Reed (1917-1979)
}

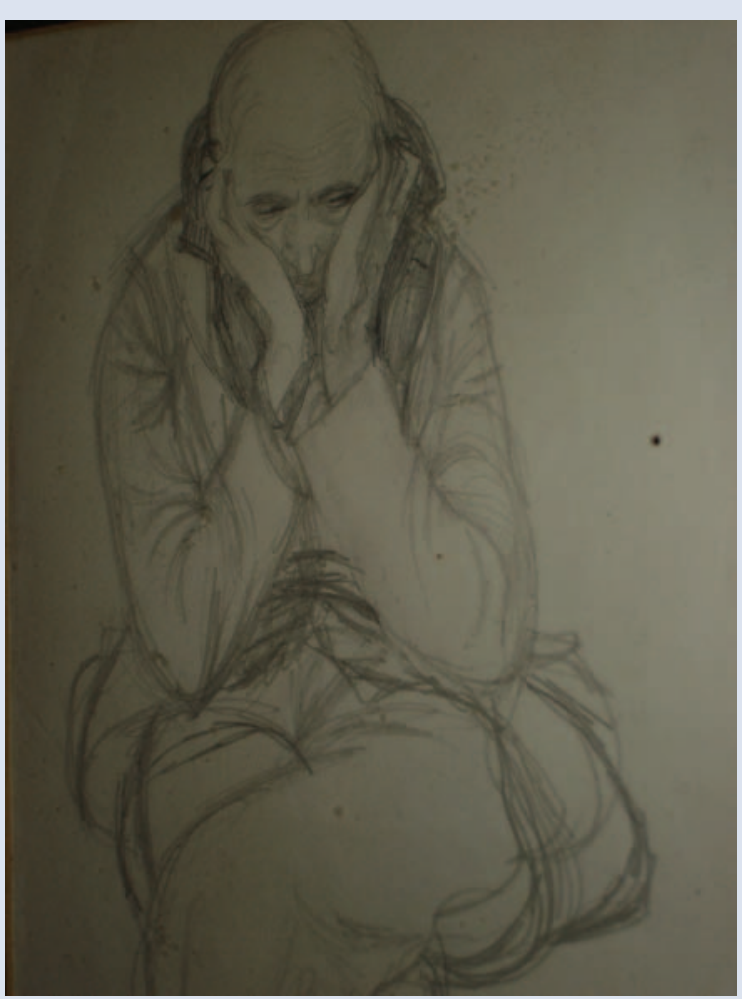

Denis Reed was born in Bristol in 1917. Despite suffering ill-health in youth, he had a happy boyhood. He enrolled at London's Royal College of Art in 1938 but his studies were interrupted by the outbreak of World War II and his subsequent enlistment in the British Army. Reed eventually qualified in 1948 and the Principal of the College, P.H. Jowett, remarked, 'His painting is always good in colour and interesting in design.' Denis Reed's work was displayed in many galleries during the post-War years. He became a member of the Royal West of England Academy and was appointed Senior Lecturer in Painting at Loughborough College of Art. Increasingly severe bouts of depression forced him to relinquish this post and he became a resident at Glenside Psychiatric Hospital in Bristol during the 1950s and 1960s.

While at Glenside, Denis Reed painted and drew prolifically. The collection of sketches and paintings provide a unique window into ward life at that time and his portraits offer an insight into the mental state both of himself and his subjects. Denis Reed died unexpectedly in 1979. In his life, he painted some 250 oils, numerous watercolours and sketches. His peers have commented on his unending interest in producing art. The details of his personal life remain almost unknown. The collection of work produced by Reed during his time at Glenside is held in the Glenside Hospital Museum in Bristol.

This image is Reed's portrayal of one of his fellow patients.

Researched by Christopher Ramsey \& Peter Carpenter, Bristol.

Edited by Allan Beveridge.

\section{Acknowledgements}

We thank Viv Jenkins and the staff of the Glenside Hospital Museum and also Tanya Wildgoose from the Royal West of England Academy for supplying Denis Reed's obituary notes.

Other pictures by Reed were published in the October 2008 issue of the Journal. 